\title{
Free-selection ethanol intake of the golden hamster (Mesocricetus auratus)
}

\author{
PAUL J. KULKOSKY \\ Laboratory of Metabolism, National Institute on Alcohol Abuse and Alcoholism \\ Rockville, Maryland 20852
}

\begin{abstract}
Female golden hamsters preferred a $10 \% \mathrm{w} / \mathrm{v}$ ethanol solution presented in a saccharin + glucose vehicle to water in free-selection tests. Although blood ethanol levels attained were higher than previously reported for rats in free-selection experiments, no symptoms of physical dependence on ethanol were apparent in a runway activity test for withdrawal.
\end{abstract}

Arvola and Forsander (1961) reported that golden hamsters show a pronounced preference for a $10 \%$ ethanol solution in 24-h two-bottle tests with water as the alternative fluid. The observed $88 \%$ free-choice preference by hamsters for the ethanol solution greatly exceeded the preferences reported for the hedgehog (Erinaceus europeus) (36.3\%), the guinea pig (Cavia porcellus) (10.8\%), the rabbit (Lepus cuniculus) (48.3\%), the albino rat (Rattus norvegicus) $(29.8 \%)$, and the Swiss albino mouse (Mus musculus) $(27.1 \%$ ). A high preference for ethanol solutions by hamsters had been noted previously (Carver, Nash, Emerson, \& Moore, 1953; Emerson, Brown, Nash, \& Moore, 1952; Forsander, Kohonen, \& Suomalainen, 1958). Subsequent reports on free-selection ethanol intake by hamsters have shown lower preferences for $10 \%$ ethanol solution, and that female hamsters typically show a lower preference for ethanol solutions than males (Arvola \& Forsander, 1963; Sinclair \& Sheaff, 1973; Slighter, 1970).

This high preference for ethanol solutions by hamsters might suggest that they are a more suitable species for laboratory studies of the effects of chronic high ethanol intake. These studies have typically employed rats, mice, or primates (Lester, 1966; Mello, 1973, 1976; Myers \& Veale, 1972; Wallgren \& Barry, 1970). However, there have been only a few studies of possible withdrawal effects after chronic ethanol intake by hamsters, and apparently none of blood ethanol levels attained during free-selection of ethanol by hamsters. These measures are of critical importance to investigators seeking a valid and convenient free-selection animal model of the effects of sustained high ethanol intake (Lester \& Freed, 1973).

This research was supported by a National Institute on Alcohol Abuse and Alcoholism staff fellowship to P. J. Kulkosky. The author thanks Patsy Sampson, Georganne Moller, and Tony Riley for their helpful suggestions, and Calvin Crutchfield and John Peterson for their expert assistance. Requests for reprints should be sent to Paul J. Kulkosky, National Institute on Alcohol Abuse and Alcoholism, 12501 Washington Avenue, Rockville, Maryland 20852.
In the following experiment, hamster ethanol intake, preference, blood levels, and withdrawal effects were examined. Female hamsters were given prolonged access to food, water, and either a $10 \% \mathrm{w} / \mathrm{v}$ ethanol/water solution or a $10 \% \mathrm{w} / \mathrm{v}$ ethanol/.125\% sodium saccharin $+3,0 \%$ glucose solution. Sweetening of the available ethanol solution with saccharin or sugars has frequently been employed to elicit an increase in intake of ethanol across a variety of species (e.g., Cullen, Croes, \& Gillis, 1973; Eriksson, 1969; Geiger \& Barker, 1976; Gilbert, 1974; Myers \& Tytell, 1972; Rodgers \& McClearn, 1964; Samson \& Falk, 1974), but this effect has not been reported for hamsters. However, hamsters are known to greatly prefer a sweetened solution to water in two-bottle tests (Carpenter, 1956; Zucker, Wade, \& Ziegler, 1972). Preliminary work (Kulkosky \& Peterson, unpublished observations) had shown that hamsters will preferentially select very large amounts of a saccharin + glucose solution in two-bottle tests with water, as Valenstein, Cox, and Kakolewski (1967) originally demonstrated with albino rats. In addition to measures of ethanol intake, preference, and blood ethanol levels attained during free selection of ethanol solution, a runway activity test (Pohorecky, 1976) was used to measure possible withdrawal effects consequent to removal of ethanol solutions.

\section{METHOD}

\section{Subjects}

Subjects were 12 experimentally naive female golden hamsters [outbred, Lakeview Lak:LVG (SYR)], approximately 6 months of age at the beginning of the experiment. They were individually housed in $10.5 \times 9.5 \times 8$ in. $(26.7 \times 24.1 \times 20.3 \mathrm{~cm})$ polycarbonate cages with $3 \times 3$ in. $(7.6 \times 7.6 \mathrm{~cm})$ stainless steel wiremesh floors at an ambient temperature of $20^{\circ} \mathrm{C}$ with a $1: 23$ L:D cycle. They had ad-lib access to Purina NIH open formula rat and mouse ration and deionized water throughout the experiment.

\section{Apparatus}

Each cage had approximately 1-in.-diam. (2.5-cm) grommeted openings 5 in. $(12.7 \mathrm{~cm})$ apart. Each grommet firmly held a stainless steel clip and a central stainless steel water valve (Lab 
Table 1

Experimental Groups and Sequence of Treatments

\begin{tabular}{llllll}
\hline & \multicolumn{5}{c}{ Days } \\
\cline { 2 - 6 } Group & $1-17$ & $18-28$ & $29-33$ & 34 & $35-67$ \\
\hline $\mathrm{H}$ & $\mathrm{H}_{2} \mathrm{O}$ & $\mathrm{H}_{2} \mathrm{O}$ & $\mathrm{H}_{2} \mathrm{O}$ & $\mathrm{H}_{2} \mathrm{O}$ & $\mathrm{H}_{2} \mathrm{O}$ \\
SGE-E & $\mathrm{SGE}$ & $\mathrm{E}$ & SGE & $\mathrm{H}_{2} \mathrm{O}$ & SGE \\
E-SGE & E & SGE & SGE & $\mathrm{H}_{2} \mathrm{O}$ & SGE \\
\hline
\end{tabular}

Products, Inc.) with a tip that was placed approximately $1 / 16$ in. $(.15 \mathrm{~cm})$ beyond the grommet outside the cage. The watering valve was attached by means of tubing to a closed, calibrated $60-\mathrm{ml}$ plastic syringe. Spillage was captured by a $12-\mathrm{ml}$ calibrated syringe positioned outside the cage and directly beneath the water valve. Relative positions of test fluids were alternated at each measurement of intake. Fluid intakes and spillage were measured to the nearest $1.0 \mathrm{ml}$.

\section{Procedure}

The experimental groups and treatment sequence are summarized in Table 1. All hamsters had ad-lib access to water and chow for a period of 3 months. Subjects were randomly assigned to one of three groups. Hamsters in Group $\mathrm{H}(\mathrm{N}=6)$ continued to receive ad-lib water and chow throughout the experiment. Hamsters in Group SGE-E $(\mathbf{N}=3)$ received ad-lib access to chow, deionized water, and a solution of $3.0 \% \mathrm{w} / \mathrm{v}$ glucose (anhydrous dextrose, Baker reagent), $.125 \% \mathrm{w} / \mathrm{v}$ sodium saccharin (Fisher purified), and $10 \% \mathrm{w} / \mathrm{v}$ ethanol (from U.S.P. 95\%) in deionized water (SGE) for an initial period of 17 days. Intakes were measured daily except for occasional 2-3-day intervals, when mean daily intakes were determined. Hamsters in Group E-SGE $(\mathrm{N}=3)$ received ad-lib access to chow, deionized water, and a solution of $10 \% \mathrm{w} / \mathrm{v}$ ethanol in deionized water (E) for this initial period. After this period, treatments of hamsters receiving ethanol were reversed, such that hamsters in Group SGE-E received access to chow, water, and $10 \% \mathrm{w} / \mathrm{v}$ ethanol in deionized water, and vice versa, for a period of 11 days. After this period, both of these groups of hamsters received access to water, chow, and $10 \% \mathrm{w} / \mathrm{v}$ ethanol in saccharin + glucose solution for an additional 5 days. On the 5th day, each hamster receiving ethanol and each hamster receiving only water was placed at noon in a $200 \times 15 \times 15 \mathrm{~cm}$ runway of painted wood with a hinged Plexiglas top, as described by Pohorecky (1976). The hamsters were placed at one end of the runway delimited by a line $10 \mathrm{in} .(25.4 \mathrm{~cm})$ from the wall, and the time to complete the first run (defined as a crossing of the corresponding line at the other end) and the total number of runs made in $5 \mathrm{~min}$ were recorded. After this test, all hamsters received only chow and water. At the same time on the following day, all subjects were again placed in the runway and tested as previously. Pohorecky (1976) has shown that rats undergoing ethanol withdrawal at these time parameters display greatly decreased locomotor activity compared to controls in this runway, as indexed by decreased number of runs per trial and increased time required to complete the first run.

Following the runway test, hamsters in Groups SGE-E and E-SGE again received access to water, chow, and $10 \%$ ethanol in saccharin + glucose solution for a period of 33 days. On the 8th day of this period, all hamsters receiving ethanol were removed from their cages at midnight, anaesthetized with ether, and a $.15-\mathrm{ml}$ blood sample was obtained by cardiac puncture with a 5/8-in. (1.6-cm) 25-ga needle. On Day 20, all hamsters receiving either ethanol solution or water only were removed from their cages at noon and blood sampled as described above. Blood ethanol determinations were made in duplicate, with yeast alcohol dehydrogenase, as described by Dickinson and Dalziel (1967).

Data were analyzed with one- and two-way analyses of variance, regression correlation analysis, and two-tailed $t$ tests (with $\mathrm{p}<.05$ as significant).

\section{RESULTS}

Grams of absolute ethanol per kilogram of body weight per day intakes of Groups SGE-E and E-SGE

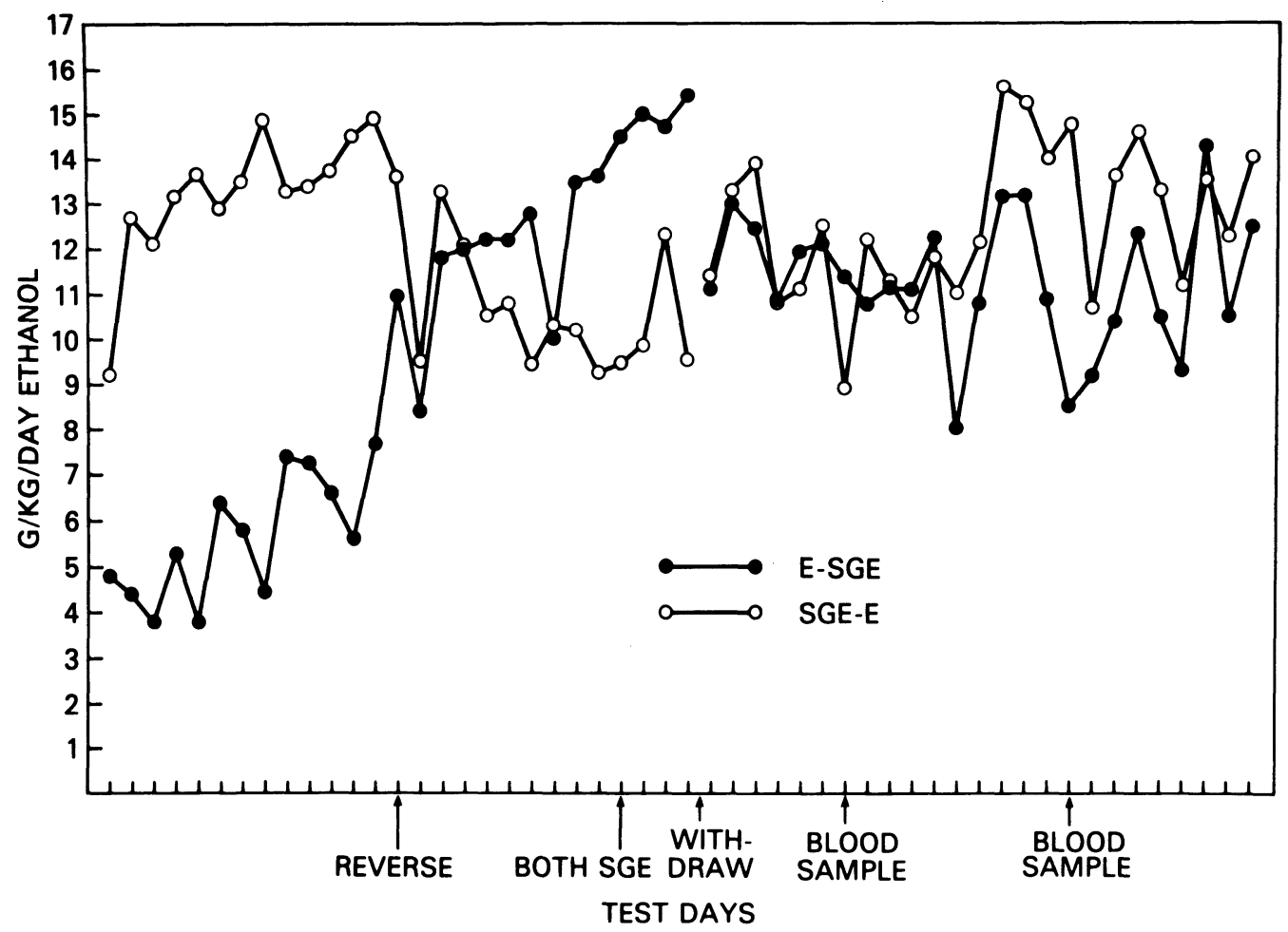

Figure 1. Mean ethanol intakes (in $\mathrm{g} / \mathrm{kg} / \mathrm{day}$ ) of hamsters initially receiving sweetened $10 \%$ ethanol (Group SGE-E, open circles) or initially receiving unsweetened $10 \%$ ethanol (Group E-SGE, solid circles) across test days. 
Table 2

Ethanol Intakes, Water Intakes, and Ethanol Solution/Total Fluid Ratios

\begin{tabular}{|c|c|c|c|c|c|c|c|c|c|c|c|c|c|}
\hline \multirow[b]{2}{*}{ Group } & \multicolumn{3}{|c|}{ Days 1-17 } & \multicolumn{3}{|c|}{ Days $18-28$} & \multicolumn{3}{|c|}{ Days 29-33 } & \multirow{2}{*}{$\begin{array}{c}\text { Day } 34 \\
\mathrm{H}_{2} \mathrm{O}\end{array}$} & \multicolumn{3}{|c|}{ Days 35-67 } \\
\hline & Ethanol & $\mathrm{H}_{2} \mathrm{O}$ & $\mathrm{E} / \mathrm{T}$ & Ethanol & $\mathrm{H}_{2} \mathrm{O}$ & $\mathrm{E} / \mathrm{T}$ & Ethanol & $\mathrm{H}_{2} \mathrm{O}$ & $\mathrm{E} / \mathrm{T}$ & & Ethanol & $\mathrm{H}_{2} \mathrm{O}$ & $\mathrm{E} / \mathrm{T}$ \\
\hline $\begin{array}{l}\text { SGE-E } \\
\text { E-SGE } \\
\text { H }\end{array}$ & $\begin{array}{r}13.3 \\
5.8\end{array}$ & $\begin{array}{r}8.2 \\
18.9\end{array}$ & $\begin{array}{l}.73 \\
.20\end{array}$ & $\begin{array}{l}12.2 \\
12.1\end{array}$ & $\begin{array}{l}3.9 \\
9.3\end{array}$ & $\begin{array}{l}.79 \\
.60\end{array}$ & $\begin{array}{l}12.0 \\
15.9\end{array}$ & $\begin{array}{r}6.6 \\
12.0\end{array}$ & $\begin{array}{l}.69 \\
.58\end{array}$ & $\begin{array}{l}31.3 \\
21.0 \\
23.0\end{array}$ & $\begin{array}{l}14.2 \\
12.7\end{array}$ & $\begin{array}{l}4.9 \\
7.4\end{array}$ & $\begin{array}{l}.8 \\
.7\end{array}$ \\
\hline
\end{tabular}

are summarized in Figure 1. During the initial period, ethanol intake of the group receiving access to sweetened $10 \%$ ethanol averaged $13.2 \mathrm{~g} / \mathrm{kg} / \mathrm{day}$, and was significantly different from that of the group receiving unsweetened ethanol, $5.6 \mathrm{~g} / \mathrm{kg} /$ day $(\mathrm{F}=53.2$, $\mathrm{df}=1,52, \mathrm{p}<.001$ ). Ethanol solution intakes (in milliliters), water intakes (in milliliters), and the ethanol-solution/total-fluid intake ratios (E/T ratio) for the SGE-E and E-SGE groups across treatments are summarized in Table 2.

During the period of treatment reversal, ethanol intake of the SGE-E group averaged $10.9 \mathrm{~g} / \mathrm{kg} / \mathrm{day}$ and did not differ significantly from that of the E-SGE group, $11.8 \mathrm{~g} / \mathrm{kg} /$ day $(\mathrm{F}=.67, \mathrm{df}=1,40$, $\mathrm{p}>$.05).

Ethanol intake of the SGE-E group was significantly different from that of the E-SGE group in the period immediately prior to the withdrawal period, 10.3 vs. $14.9 \mathrm{~g} / \mathrm{kg} /$ day, respectively $(\mathrm{F}=33.5, \mathrm{df}=1,16$, $\mathrm{p}<.001)$. During the $24-\mathrm{h}$ period when ethanol solutions were withdrawn, water intakes of the three groups did not differ significantly $(F=.41$, df $=2,9$, $\mathrm{p}>.05)$.

In the period following the withdrawal test, ethanol intakes of the SGE-E and E-SGE groups averaged 12.6 and $11.3 \mathrm{~g} / \mathrm{kg} /$ day, respectively, and did not differ significantly $(F=3.12, \mathrm{df}=1,100, \mathrm{p}>.05)$.

During the first trial in the runway, hamsters maintained on only water made an average of 12.8 runs in $5 \mathrm{~min}$ and took an average of $31.5 \mathrm{sec}$ to complete the first run. These values did not differ significantly from those of the hamsters with access to $10 \%$ ethanol, 8.3 runs $(\mathrm{t}=1.69, \mathrm{df}=10, \mathrm{p}>.05)$ and $25.2 \mathrm{sec}(\mathrm{t}=1.09$, df $=10, \mathrm{p}>.05)$. During the trial after removal of ethanol solutions, hamsters maintained on water only throughout the experiment made an average of 8.7 runs and took an average of $17.2 \mathrm{sec}$ to complete the first run. Again, these values did not differ significantly from those of the hamsters with prior access to $10 \%$ ethanol, 7.3 runs $(t=.89$, $\mathrm{df}=10, \mathrm{p}>.05)$ and $16.2 \mathrm{sec}(\mathrm{t}=.22$, df $=10$, $\mathrm{p}>.05)$. Also, the mean pre-post withdrawal changes in runs $(\mathrm{t}=1.72, \mathrm{df}=10, \mathrm{p}>.05)$ and time to first run $(\mathrm{t}=.94, \mathrm{df}=10, \mathrm{p}>.05)$ of the two groups were not significantly different.

Blood ethanol determinations in $\mathrm{mg} / \mathrm{dl}$ and $\mathrm{g} / \mathrm{kg} / 24$-h ethanol intakes (intakes $\times 2$ for midnight samples) at the two sampling times are presented in Table 3. Blood ethanol values for the hamsters re- ceiving $10 \%$ ethanol ranged between $.0-242.4 \mathrm{mg} / \mathrm{dl}$ with a mean of $59.6 \mathrm{mg} / \mathrm{dl}(12.9 \mathrm{mM})$ at midnight, and ranged between .6 and $91.8 \mathrm{mg} / \mathrm{dl}$, with a mean of $34.1 \mathrm{mg} / \mathrm{dl}(7.4 \mathrm{mM})$ at noon, for a grand mean of $46.9 \mathrm{mg} / \mathrm{dl}(10.2 \mathrm{mM})$. Noon blood ethanol values for the hamsters receiving only water ranged between .0 and $7.2 \mathrm{mg} / \mathrm{dl}$ with a mean of $4.1 \mathrm{mg} / \mathrm{dl}$ (.9 mM). Mean 24-h ethanol intake and mean blood ethanol level of the 12 hamsters were significantly correlated $(r=.74$, df $=10, p<.01)$; the leastsquares fit equation is: $y$ (in $\mathrm{mg} / \mathrm{dl}$ ) $=.612+4.58 \mathrm{x}$ (in $\mathrm{g} / \mathrm{kg} /$ day).

\section{DISCUSSION}

The data of this experiment show that female hamsters, offered a choice between water and a $10 \% \mathrm{w} / \mathrm{v}$ ethanol solution, display only a low preference (.2) for the ethanol solution. However, if the ethanol is presented in a sweetened vehicle, it is clearly preferred to water (.73). Many investigators have demonstrated that sweetening of the available ethanol solution increases ethanol intake in free-choice situations with rats, mice, and primates; the present experiment shows the effect of sweetening in hamsters. However, reversal of vehicle treatment did not result in an abrupt decline of ethanol intake by hamsters previously receiving sweetened ethanol solution, although it did result in a substantial increase in ethanol intake

Table 3

Ethanol Intakes and Blood Ethanol Levels

\begin{tabular}{|c|c|c|c|c|}
\hline \multirow[b]{4}{*}{ Subject } & \multicolumn{4}{|c|}{ Sampling Time } \\
\hline & \multicolumn{2}{|c|}{ Midnight } & \multicolumn{2}{|c|}{ Noon } \\
\hline & \multicolumn{2}{|c|}{$\mathrm{g} / \mathrm{kg}$} & \multicolumn{2}{|c|}{$\mathrm{g} / \mathrm{kg} /$ Day } \\
\hline & Intake $(\times 2)$ & $\mathrm{mg} / \mathrm{dl}$ & Intake & $\mathrm{mg} / \mathrm{dl}$ \\
\hline 16 & & & 0.0 & 2.5 \\
\hline 22 & 12.4 & 45.9 & 8.2 & .6 \\
\hline 23 & & & 0.0 & 0.0 \\
\hline 25 & & & 0.0 & 3.3 \\
\hline 26 & & & 0.0 & 7.2 \\
\hline 36 & 19.7 & 56.1 & 12.7 & 91.8 \\
\hline 31 & & & 0.0 & 7.2 \\
\hline 41 & 4.3 & 0.0 & 18.3 & 67.7 \\
\hline 43 & 6.5 & 3.4 & 13.2 & 28.1 \\
\hline 45 & & & 0.0 & 4.6 \\
\hline 52 & 11.9 & 242.4 & 12.8 & 10.4 \\
\hline 54 & 5.8 & 10.0 & 4.7 & 6.1 \\
\hline
\end{tabular}


by hamsters previously receiving unsweetened ethanol solution. The observed gradual decline in ethanol intake by hamsters previously receiving sweetened ethanol solution may have led to a significant group effect of vehicle treatment reversal, had the reversal period been extended. This finding contrasts with the sharp decline in ethanol intake by rats after removal of sucrose from the solution reported by Cullen, Croes, and Gillis (1973). However, the sustained intake after removal of sweetening does resemble the pattern of retained increased preference for ethanol solution independent of lowered sucrose content of solution exhibited by some mice (Rodgers \& McClearn, 1964). This effect might be variously interpreted as a conditioned preference, and/or the development of a metabolic tolerance, or simply as a fortuitous initial group difference, similar to that reported by Sinclair and Scheaff (1973).

The range of mean ethanol intakes observed in the present experiment (.74-2.02 $\mathrm{ml}$ absolute ethanol/ hamster/day) is within the range of mean intakes previously reported for female hamsters across the ethanol concentration range of 7\%-40\% v/v (.4-2.5 ml absolute ethanol/hamster/day) (see table of Sinclair $\&$ Sheaff, 1973). The hamsters in the present experiment demonstrated much higher blood ethanol levels $(\bar{X}=46.9 \mathrm{mg} / \mathrm{dl})$ than previously reported for rats in free-selection situations (e.g., Lester \& Greenberg, 1952-range: $0-31 \mathrm{mg} / \mathrm{dl}, \overline{\mathrm{X}}=6.5 \mathrm{mg} / \mathrm{dl}$; Kulkosky \& Peterson, Note 1 -range: $2-32.6 \mathrm{mg} / \mathrm{dl}, \bar{X}=$ $15.3 \mathrm{mg} / \mathrm{dl}$ ). However, there was no evidence of withdrawal effects upon removal of ethanol solution, and no consistent observations of behavioral impairment either recorded during the runway test or made incidentally during intake measurements. This indicates that although hamsters may achieve higher blood ethanol levels than rats in a free-selection situation, these levels are either not high enough or they fluctuate too widely to result in unequivocal signs of withdrawal (Samson \& Falk, 1975). The hamsters in the present experiment also appear to exhibit a higher preference for sweetened or unsweetened $10 \% \mathrm{w} / \mathrm{v}$ ethanol solution than rats. Two groups of three male Wistar rats each exhibited mean preferences of .51 and .07 for $10 \% \mathrm{w} / \mathrm{v}$ SGE and E solutions, respectively, when tested under similar conditions for 17 days. When vehicles were reversed, mean $\mathrm{E} / \mathrm{T}$ of rats previously receiving sweetened $10 \%$ ethanol promptly dropped to .08 and mean E/T of rats previously receiving unsweetened $10 \%$ ethanol promptly rose to .44 , a result similar to that reported for rats by Cullen, Croes, and Gillis (1973).

In summary, the golden hamster appears to exhibit a sustained high preference for a sweetened $10 \% \mathrm{w} / \mathrm{v}$ ethanol solution and attains higher blood ethanol levels than previously reported for rats in freeselection situations. However, this intake of ethanol is apparently not sufficient to produce obvious signs of physical dependence upon ethanol. ${ }^{1}$

\section{REFERENCE NOTE}

1. Kulkosky, P. J., \& Peterson, N. J., Jr. Effect of addition of ethanol and $\mathrm{NaCl}$ on saccharin + glucose polydipsia. Paper presented at the 48th Annual Meeting of the Eastern Psychological Association, Boston, Massachusetts, April 1977.

\section{REFERENCES}

Arvola, A., \& Forsander, O. Comparison between water and alcohol consumption in six animal species in free-choice experiments. Nature, 1961, 191, 819-820.

Arvola, A., \& Fors ANDER, O. A. Hamsters in experiments of free choice between alcohol and water. Quarterly Journal of Studies on Alcohol, 1963, 24, 591-597.

CARPENTER, J. A. Species differences in taste preferences. Journal of Comparative and Physiological Psychology, 1956, 49, 139-144.

Carver, J. W., Nash, J. B., Emerson, G. A., \& Moore, W. T. Effect of pregnancy and lactation on voluntary alcohol intake of hamsters. Federation Proceedings, 1953, 12, 309.

Cullen, J. W., Croes, R. A., \& Gillis, R. D. Alcohol selection by rats after experience with a sapid alcohol-sucrose solution. Quarterly Journal of Studies on Alcohol, 1973, 34, 769-773.

Dickinson, F. M., \& Dalziel, K. The specificities and configurations of ternary complexes of yeast and liver alcohol dehydrogenases. Biochemical Journal, 1967, 104, 165-172.

Emerson, G. A., Brown, R. G., Nash, J. B., \& Moore, W. T. Species variation in preference for alcohol and in effects of diet or drugs on this preference. Journal of Pharmacology and Experimental Therapeutics, 1952, 106, 384.

ERIKSSON, K. Factors affecting voluntary alcohol consumption in the albino rat. Annales Zoologici Fennici, 1969, 6, 227-265.

Forsander, O., Kohonen, J., \& Suomalainen, H. Physiological alcohol consumption. Quarterly Journal of Studies on Alcohol, 1958, 19, 379-387.

GEIGER, J. F., \& BARKer, L. M. Alcohol consumption by rat and mouse strains: Functions of taste and alcohol deprivation. Journal of Studies on Alcohol, 1976, 37, 950-958.

GILBERT, R. M. Effects of food deprivation and fluid sweetening on alcohol consumption by rats. Quarterly Journal of Studies on Alcohol, 1974, 35, 42-47.

LESTER, D. Self-selection of alcohol by animals, human variation, and the etiology of alcoholism: A critical review. Quarterly Journal of Studies on Alcohol, 1966, 27, 395-438.

Lester, D., \& Freed, E. X. Criteria for an animal model of alcoholism. Pharmacology, Biochemistry, and Behavior, 1973, 1, 103-107.

LESTER, D., \& GREenberg, L. A. Nutrition and the etiology of alcoholism: The effect of sucrose, saccharin and fat on the selfselection of ethyl alcohol by rats. Quarterly Journal of Studies on Alcohol, 1952, 13, 553-560.

McMillan, D. E., Ellis, F. W., Frye, G. D., \& Pick, J. R. Failure of signs of physical dependence to develop in hamsters after prolonged consumption of large doses of ethanol. Pharmacology, Biochemistry, and Behavior, 1977, 7, 55-57.

Mello, N. K. A review of methods to induce alcohol addiction in animals. Pharmacology, Biochemistry, and Behavior, 1973, 1, 89-101.

Mello, N. K. Animal models for the study of alcohol addiction. Psychoneuroendocrinology, 1976, 1, 347-357.

Myers, R. D., \& Tytell, M. Volitional consumption of flavored ethanol solution by rats: The effects of pCPA, and the absence of tolerance. Physiology \& Behavior, 1972, 8, 403-408.

Myers, R. D., \& Veale, W. L. The determinants of alcohol preference in animals. In B. Kissin \& $\mathrm{H}$. Begleiter (Eds.), The biology of alcoholism (Vol. 2) Physiology and behavior, New York: Plenum, 1972.

Poнorecky, L. A. Withdrawal from ethanol: Simple quantitative behavioral tests for its evaluation. Psychopharmacology, 1976, 50, 125-129.

Rodgers, D. A., \& McClearn, G. E. Sucrose versus ethanol appetite in inbred strains of mice. Quarterly Journal of Studies on Alcohol, 1964, 25, 26-35. 
Samson, H. H., \& Falk, J. L. Schedule-induced ethanol polydipsia: Enhancement by saccharin. Pharmacology, Biochemistry, and Behavior, 1974, 2, 835-838.

Samson, H. H., \& FalK, J. L. Pattern of daily blood ethanol elevation and the development of physical dependence. Pharmacology, Biochemistry, and Behavior, 1975, 3, 1119-1123.

SinclaIR, J. D., \& ShEAFF, B. A negative alcohol-deprivation effect in hamsters. Quarterly Journal of Studies on Alcohol, 1973, 34, 71-77.

Slighter, R. G., JR. Alcohol selection and position selection in hamsters caged singly and in groups. Quarterly Journal of Studies on Alcohol, 1970, 31, 20-27.

Valenstein, E. S., Cox, V. C., \& Kakolewski, J. W. Polydipsia elicited by the synergistic action of a saccharin and glucose solution. Science, 1967, 157, 552-554.

W Allgren, H., \& BARRY, H., III. Actions of alcohol. New York: Elsevier, 1970.
Zucker, I., WAde, G. N., \& Ziegler, R. Sexual and hormonal influences on eating, taste preferences, and body weight of hamsters. Physiology \& Behavior, 1972, 8, 101-111.

\section{NOTES}

1. Subsequent to the completion of this manuscript, McMillan, Ellis, Frye, and Pick (1977) reported that male hamsters freely selecting an average of $13.8 \mathrm{~g} / \mathrm{kg} /$ day of ethanol for 3 months did not exhibit withdrawal signs during a 4-day ethanol withdrawal period, as indexed by audiogenic seizures, activity wheel counts, and body weight changes. After 4 more months of ethanol intake, again no withdrawal signs or liver abnormalities were observed.

(Received for publication September 15, 1977; Revision accepted August 15, 1978.) 